\title{
Microcrustacean diversity in the Gemenc-Béda-Karapancsa Floodplains (Danube-Drava National Park, Hungary): rare and alien species
}

\author{
A. Kiss, E. ÁGoston-SzabÓ, M. DinKa \& Á. BerCZIK \\ Anita Kiss, Edit Ágoston-Szabó, Mária Dinka \& Árpád Berczik, Centre for Ecological Research of HAS Danube \\ Research Institute, H-1113, Budapest, Karolina út 29. Hungary, kiss.anita@okologia.mta.hu, agoston- \\ szabo.edit@okologia.mta.hu,dinka.maria@okologia.mta.hu,berczik.arpad@okologia.mta.hu
}

\begin{abstract}
The composition of microcrustacean fauna was investigated in different water bodies of Gemenc-Béda-Karapancsa Floodplains with special regard to the distribution of alien and rare taxa. Between 2002 and 2013101 taxa (57 Cladocera, 27 Copepoda, 17 Ostracoda,) were recorded from the water bodies with differing degrees of connectivity to the main river (eu-, para-, plesio- and paleopotamon). 18 species are reported for the first time from the area of Danube-Drava National Park and among them Daphnia ambigua, Pleuroxus denticulatus and Eurytemora velox are allochtonous species in Hungary. E. velox and $P$. denticulatus have persistent populations in the area, but their contribution to floodplain biodiversity is still not significant. Daphnia ambigua has only local and temporal populations and its presence is confined to the disconnected side of the floodplain. The abundance of thirty species was very low and their distribution pattern in the floodplain is different. The microcrustacean diversity of the plesiopotamal side arms is remarkable, particularly in the Nyéki-Holt-Danube.
\end{abstract}

Keywords. Alien species, Cladocera, Copepoda, Ostracoda, species richness, Gemenc-Béda-Karapancsa Floodplains.

\section{INTRODUCTION}

$\mathrm{F}^{\mathrm{s}}$ loodplains are an important area of biodiversity, providing habitat for endangered or threatened species. Floodplain rivers are disturbance-dominated ecosystems characterized by high levels of habitat diversity and biota adapted to exploit the spatio-temporal heterogeneity (Junk et al. 1989, Amoros \& Roux 1988, Ward \& Stanford 1995). Ecotones, hydrological connectivity, and succession processes play major role in structuring the spatio-temporal heterogeneity leading to the high biodiversity that characterizes floodplain rivers.

The Gemenc-Béda-Karapancsa Floodplains of the Danube River (rkm 1497-1440) part of the Danube-Drava National Park (Hungary) represents an exceptional example of river-floodplain systems in Europe with meanders, oxbow lakes, marshlands, and extended hardwood forests. These floodplains are also Natura 2000 areas and form an UNESCO Biosphere Reserve. This area is the largest active floodplain in Europe with unique natural value (Zinke 1996). It lies completely within the dike system, namely the characteristic hydrological processes of the river floodplain system are not disturbed.

Limited number of studies is dealing with the Cladocera, Copepoda and Ostracoda fauna of this area. The first data was presented by Bothár (1980) describing 18 Cladocera and 10 Copepoda species in the Vén-Danube and in the main arm near Baja. In 1994 Körmendi (2007) recorded 10 Cladocera and 10 Copepoda taxa from different dead arms and temporary pools of Gemenc floodplain. The most comprehensive description of the fauna was published by Forró \& Meisch (1998). Their studies revealed 118 crustacean species (Anostraca, Notostraca, Cladocera, Copepoda, Ostracoda, Isopoda, Amphipoda and Mysida) from the Drava region of the Danube-Drava National Park based on collectings between 1995

urn:1sid:zoobank.org:pub:7D172826-9C0F-41C0-9B58-8CC14DF83FF5

HU ISSN 2063-1588 (online), HU ISSN 0237-5419 (print) http://dx.doi.org/10.18348/opzool.2015.2.183 
and 1997. In 1999 Körmendi and Lanszki (2002) recorded 37 Cladocera and 11 Copepoda taxa from various water bodies of Danube-Drava National Park. Between 1997 and 1998 Csányi et al. (1998) examined the zooplankton assemblages in the Vén-Danube, Nyéki-Holt-Danube and the main arm near to Baja reporting on 15 zooplankton taxa.

Between 2002 and 2013 detailed investigations were carried out and part of this project was to examine the zooplankton assemblages in water bodies with differing degrees of connectivity to the main river on a near natural temperate riverfloodplain system (e.g. Schöll \& Kiss 2008, Kiss \& Schöll 2009, Kiss et al. 2014).

Here we summarize the faunistic results of this long-term study focusing the presence and distribution of rare and alien microcrustacean species and furthermore, the species composition of different water bodies on the floodplain.

\section{MATERIALS AND METHODS}

\section{Study area}

Covering some 25,000 ha, the Gemenc-BédaKarapancsa Floodplains of the Danube River is situated between rkm 1497 and 1440. In this reach the mean annual discharge is $2400 \mathrm{~m}^{3} \mathrm{~s}^{-1}$, with a minimum of $618 \mathrm{~m}^{3} \mathrm{~s}^{-1}$ and a maximum of 7940 $\mathrm{m}^{3} \mathrm{~s}^{-1}$. The water level is monitored by an official gauge at Baja (rkm 1479; $46^{\circ} 10,41^{\prime} \mathrm{N}, 18^{\circ}$ $55,29^{\prime} \mathrm{E}$ ), which recorded a maximum amplitude of $9 \mathrm{~m}$. In the main arm the slope is about $5 \mathrm{~cm}$ $\mathrm{km}^{-1}$, with a velocity of $0.8-1.2 \mathrm{~m} \mathrm{~s}^{-1}$ at mean water level. The river starts to overflow into the floodplain above a water level of $500 \mathrm{~cm}$ at Baja.

Different riverine functional units can be observed in the study area, thus providing opportunity for simultaneous comparisons. The typology of the water bodies was based on the functional classification of Amoros et al. (1987), which depends on the flow velocity of the branches and on the intensity of lateral connectivity between the main channel, the side arms, and the backwaters.
For our investigation the following sites were chosen: 1. Eupotamon: the main channel, with permanent flow; bottom composed of stones, gravel and coarse sand; macrophytes are absent. 2. Parapotamon: side arms permanently connected to the main channel; bottom composed of gravel mixed with sand and silt; macrophytes are scarce. 3. Plesiopotamon: permanent or temporary standing water bodies with no permanent and direct connection to the main arm, connection with the main arm at higher water levels; upstream end is often silted up; the bottom consists of silt and clay, macrophytes could grow densely and highly influenced by the discharge of the river. 4. Paleopotamon: former anatomised channels or meanders with no direct connection to the river, slightly influenced by the river discharge, the bottom consists of silt and clay, macrophytes grow very densely (Guti 2001).

A total of 66 sampling sites were selected and divided into four functional groups: eupotamon (3 sites), parapotamon (Vén-Danube, Rezéti-HoltDanube, 12 sites), plesiopotamon (Grébeci-HoltDanube, Nyéki-Holt-Danube, Cserta-Danube, Sárkány-fok, Címer-fok, Külső-Béda, MocskosDanube, 35 sites), 4. paleopotamon (Riha Oxbow 16 sites) (Fig. 1.). Besides the regularly used sampling sites, additional sites were also selected between 2007 and 2009, during the floods (VDU5; RDU6, 7, 8, 9; GDU6) and among different macrohyte stands in the Mocskos-Danube and Riha Oxbow (19 sites). Sampling was carried out between April 2002 and October 2013, the sampling years were between 2002 and 2004, 2007 and 2009 and 2012 and 2013.

The sampling sites and sampling dates were the following:

\section{Eupotamon}

\section{Main arm of the Danube}

D1489: 1489 rkm, Érsekcsanád, N46 16,403' E18 54,547', in front of the mouth of Grébeci-Holt-Danube.

2002 (08. 04., 03. 07.), 2003 (07. 05., 08. 07., 15. 09. 27. 10.), 2004 (04. 14., 27. 05., 01. 07., 26. 08., 27. 10.), 2007 (23. 05., 11. 09., 25. 09.), 2008 (29. 07), 2009 (07. 04., 28. 
04., 03. 06., 09. 06., 11. 06., 29. 06., 21. 06., 03. 08., 01. 09., 06. 10., 27. 10.)

D1482: Baja (N46 ${ }^{\circ} 11,412^{\prime}$ E1 $\left.18^{\circ} 55,610^{\prime}\right)$

$\underline{2008}$ (29. 07.), $\underline{2009}$ (29. 06., 21. 07., 03. 08.)

D1437: 1437 rkm, Mohács, N4555,967' E18 46,433', beyond the harbour of the ferry.

2007 (25. 07., 29. 08., 25. 10.), 2008 (18.03., 10. 06.), 2009 (22. 06., 28. 07.), 2012 (16. 05., 19. 06., 04. 07., 07. 08., 04. 09., 09. 10.), 2013 (26. 06., 12. 10.)

\section{Parapotamon}

Vén-Danube (VDU)

$5 \mathrm{~km}$ long side arm with constant flow. It was the part of the main arm until the interception in $1897-1898$

VDU2 (N46 ${ }^{\circ} 11.880^{\prime}$ E1 $\left.8^{\circ} 55.177^{\prime}\right)$, VDU3 (N46 ${ }^{\circ} 12.118^{\prime}$ E18 $\left.53.843^{\prime}\right)$, VDU4 (N46⒓754' E18 $\left.{ }^{\circ} 53.940^{\prime}\right)$, small periodical inflow: VDU5 (N46 $12.346^{\prime}$ E1 $\left.8^{\circ} 53.732^{\prime}\right)$

2002 (08. 04., 02. 05., 13. 06., 03. 07., 12. 11.), 2003 (07. 05., 08. 07., 15. 09. 27. 10.), 2004 (04. 14., 27. 05., 01. 07., 26. 08., 27. 10.), 2007 (23. 05., 11. 09., 25. 09.), 2008 (29. 07.), 2009 (29. 06., 21. 07., 03. 08.)

\section{Rezéti-Holt-Danube (RDU)}

$15 \mathrm{~km}$ long side arm, it was the main arm until the interception in 1893-1894.

RDU2 (N46⒕224' E18 53.192 '), RDU3.1 (N46⒕767' E18 $\left.52.541^{\prime}\right)$, RDU4 (N46 $16.015^{\prime}$ E1 $\left.8^{\circ} 53.645^{\prime}\right)$, RDU5 (N46 $15.599^{\prime}$ E1 $\left.8^{\circ} 53.623^{\prime}\right)$, small periodical inflow: RDU6 $\left(\mathrm{N} 46^{\circ} 16.208^{\prime} \quad\right.$ E1 $\left.8^{\circ} 52.671^{\prime}\right), \quad$ RDU7 $\quad\left(N_{4} 6^{\circ} 16.237^{\prime}\right.$ E18 $\left.8^{\circ} 2.373^{\prime}\right)$, RDU9 (N4613,412' E18 $\left.{ }^{\circ} 51,967^{\prime}\right)$, stagnant temporary water body: RDU8 (N46 ${ }^{\circ} 13.950$ ' E18 ${ }^{\circ} 51.918^{\prime}$ )

2002 (08. 04., 02. 05., 13. 06., 03. 07., 12. 11.), 2003 (07. 05., 08. 07., 15. 09. 27. 10.), 2004 (04. 14., 27. 05., 01. 07., 26. 08., 27. 10.), 2007 (23. 05., 11. 09., 25. 09.), 2008 (29. 07.), 2009 (29. 06., 21. 07., 03. 08.)

\section{Plesiopotamon}

\section{Grébeci-Holt-Danube (GDU)}

$7 \mathrm{~km}$ long side arm, it was the part of the main arm until the interception in 1895-1896.

GDU1 (N46 ${ }^{\circ} 16.495^{\prime}$ E18 $\left.54.104^{\prime}\right)$, GDU2 (N46º 17.202'

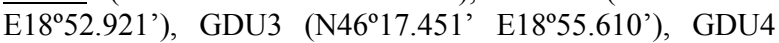
(N46 ${ }^{\circ} 17.638^{\prime} \quad$ E18 $\left.8^{\circ} 53.162^{\prime}\right), \quad$ GDU5 $\quad\left(N^{\prime} 46^{\circ} 17.641^{\prime}\right.$ E1 $\left.8^{\circ} 53.261^{\prime}\right)$, small temporary inflow: GDU6 (N46 ${ }^{\circ} 17.682^{\prime}$ E18 $\left.53.210^{\prime}\right)$

2002 (08. 04., 02. 05., 13. 06., 03. 07., 12. 11.), 2003 (07. 05., 08. 07., 15. 09. 27. 10.), 2004 (04. 14., 27. 05., 01. 07., 26. 08., 27. 10.), 2007 (23. 05., 11. 09., 25. 09.),
Nyéki-Holt-Danube (NYHD)

This strictly protected oxbow is situated in the right side of the Danube (rkm 1479) in the active floodplain. It is a natural cut-off river meander which evolved during the end of the $18^{\text {th }}$ century. The oxbow together with the Cserta-Danube, Sárkány- and Címer-fok form a complex hydrological unit. The threshold level of the surface hydrological connection of NYHD up- and downstream is reached when the water level of the Danube River at rkm 1478.7 (Baja gauge station) is $520 \mathrm{~cm}$ and $570 \mathrm{~cm}$, respectively. Upstream it is achieved through Vén-Duna (VDU), CsertaDuna (CSDU) and Sárkány-fok (SÁF), while downstream - through the Címer-fok (CIF). Its channel is silting up and it has a high macrophyte cover (Ágoston-Szabó et al. 2014).

NYHD1 ( $\left.46^{\circ} 11,642^{\prime} 18^{\circ} 50,991^{\prime}\right)$, NYHD2 (46 $11,563^{\prime} 18^{\circ}$ 50,834'), NYHD3 (46 $\left.11,489^{\prime} 18^{\circ} 50,937^{\prime}\right)$, NYHD4 (46 $\left.11,573^{\prime} 18^{\circ} 51,175^{\prime}\right)$, NYHD5 ( $\left.46^{\circ} 11,433^{\prime} 18^{\circ} 50,756^{\prime}\right)$

2003 (07. 05., 08. 07., 15. 09.), 2004 (27. 05., 01. 07.), 2009 (07. 04., 28. 04., 03. 06., 09. 06., 11. 06., 29. 06., 21. 06., 03. 08., 01. 09., 06. 10., 27. 10.)

\section{Cserta-Danube (CSDU)}

$\mathrm{CSDU}\left(\mathrm{N} 46^{\circ} 11,783^{\prime} \mathrm{E} 18^{\circ} 53,053^{\prime}\right)$ is a plesiopotamal side arm of the Vén-Danube (VDU). It together with Sárkány- and Címer-fok is part of the so-called fok-system, which are typical section of the local hydrological system. The creation of the fok-system (drainage canals) was the most important human impacts, which changed the hydrological condition of the floodplain (Guti 2001).

CSDU1 (N46 ${ }^{\circ} 11,541^{\prime}$ E18 $\left.52,431^{\prime}\right)$ CSDU2( N46ํำ $11,761^{\prime}$ E18 $\left.{ }^{\circ} 53,121^{\prime}\right)$, CSDU3 (N46 $12,133^{\prime}$ E E18 $\left.8^{\circ} 53,756^{\prime}\right)$

2003 (07. 05., 27. 10.), 2007 (25. 09.)

\section{Sárkány-fok (SÁF)}

SÁF (N46¹1,816' E18 $\left.51,594^{\prime}\right)$ is a narrow channel between the NYHD and the CSDU.

2 sampling sites

$\underline{2003}$ (07. 05., 08. 07., 15.09.)

\section{Címer-fok $(C I F)$}

CIF (N46 $\left.46,781^{\prime} \mathrm{E} 18^{\circ} 50,723^{\prime}\right)$ is a narrow channel between the NYHD and the main arm of the Danube. 2 sampling sites

$\underline{2003}(07.05$. 
Mocskos-Danube (MDU)

This side arm (rkm 1442-1440) is situated in the active floodplain of Béda-Karapancsa area. Approximately $3.4 \mathrm{~km}$ long, 60 meter wide, with shallow water (average depth: $1.5 \mathrm{~m}$ ) and very dense macrovegetation. It has a temporary connection with the Danube, the water flowing at 700 $\mathrm{cm}$ (gauge of Mohács rkm 1447) at the upper end and at $550 \mathrm{~cm}$ at the lower end of the oxbow. The water of MDU only rarely flows (1-5 times per year), and this take place only for short periods at a time (gauge of Mohács $550 \mathrm{~cm}$ ).

MDU1 (N45'57'24,8” E1846'24,7”), MDU2 (N4557'35,3”

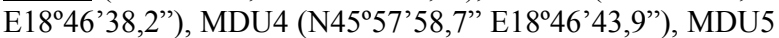

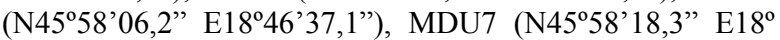
$\left.45^{\prime} 57,1^{\prime \prime}\right)$ and further seven sampling points among the submerged macrovegetation near to the regularly used sites.

$\underline{2009}$ (22. 06., 28. 07.), $\underline{2012}$ (16. 05., 19. 06., 04. 07., 07. 08., 04. 09., 09. 10.), 2013 (26. 06., 23. 07., 18. 09.)

\section{Külsö-Béda (BDU)}

It is situated on the right bank of the Danube (N45 $55,767^{\prime}$ E18 $\left.{ }^{\circ} 45,420^{\prime}\right)$ in the active floodplain of Béda-Karapancsa. Its open water area is 4 $\mathrm{km}$ long, $90 \mathrm{~m}$ wide on average and is about 2.5 $\mathrm{m}$ deep. Its upstream junction with main channel of the Danube is at the rkm 1440.5, while the downstream junction, the mouth is at rkm 1437.5 of the Danube. The upstream surface connection of BDU occurs only during high floods, above $630 \mathrm{~cm}$ water level of the Danube (at gauge of Mohács rkm 1447) (Ágoston-Szabó et al. 2013). 5 sampling sites

2007 (25. 07., 29. 08., 25. 10.), $\underline{2008}$ (18. 03., 10. 06.)

\section{Paleopotamon}

\section{Riha Oxbow (RIH)}

This oxbow is located on the protected side of the floodplain and it has no connection with the main channel. It is $4.5 \mathrm{~km}$ long and $80 \mathrm{~m}$ wide. The average water depth is approximately 1-1.5 $\mathrm{m}$. It is a strictly protected nature reserve areas covered by dense macrovegetation.

RIH1 (N4600'08,1" E1844'33,9"), RIH21 (N4600'44,6"

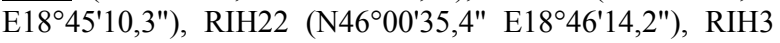
(N46 $\left.00^{\prime} 09,6^{\prime \prime} \mathrm{E} 18^{\circ} 46^{\prime} 30,9^{\prime \prime}\right)$ and further 12 sampling points among the submerged macrovegetation near to the regularly used sites. $\underline{2012}$ (16. 05., 19. 06., 04. 07., 07. 08., 04. 09., 09. 10.), 2013 (26. 06., 23. 07., 18. 09.)

\section{Collecting and identification}

Microcrustaceans were collected with plankton net (mesh size $70 \mu \mathrm{m}, \mathrm{N}=1$ ) by filtering $10 \times 10$ $\mathrm{L}$ of water from the main arm and $5 \times 10 \mathrm{~L}$ of water from the side arms, then preserved in $4 \%$ formalin. The three examined groups of crustaceans were enumerated by using inverted microscopy and identified to species level. Microcrustacean abundance, including copepodids, was evaluated by enumerating individuals in the whole sample. Gulyás \& Forró (1999, 2001), Meisch (2000) and the nomenclature of Dussart (1967, 1969) were used for species identification.

\section{RESULTS AND DISCUSSION}

\section{Faunistic results}

Between 2002 and 2013101 taxa (57 Cladocera, 27 Copepoda, 17 Ostracoda,) were recorded (Appendix 1) and 18 species reported which have not been mentioned earlier from the area of Duna-Drava National Park. These are the followings: Cladocera: Alona intermedia Sars, 1862; Bosmina longispina Leydig, 1860; Ceriodaphnia dubia Richard, 1894; Chydorus gibbus Sars, 1890; Daphnia ambigua Scourfield, 1946; Dunhevedia crassa King, 1853; Holopedium gibberum Zaddach, 1855; Pleuroxus denticulatus Birge, 1879; Copepoda: Canthocamptus staphylinus (Jurine, 1820); Cyclops insignis Claus, 1857; Cyclops scutifer Sars, 1863; Eurytemora velox (Lilljeborg, 1853); Paracyclops affinis (Sars, 1863); Ostracoda: Bradleycypris obliqua (Brady, 1868), Bradleystrandesia reticulata (Zaddach, 1844); Cypris pubera O. F. M., 1776; Notodromas monacha (O. F. Müller, 1776); Paracandona euplectella (Robertson, 1889).

Most of the collected microcrustacean species are widespread and characteristic of the fauna of the littoral zone in floodplain water bodies and lakes. The number of the detected taxa was significantly higher than the published results of pre 


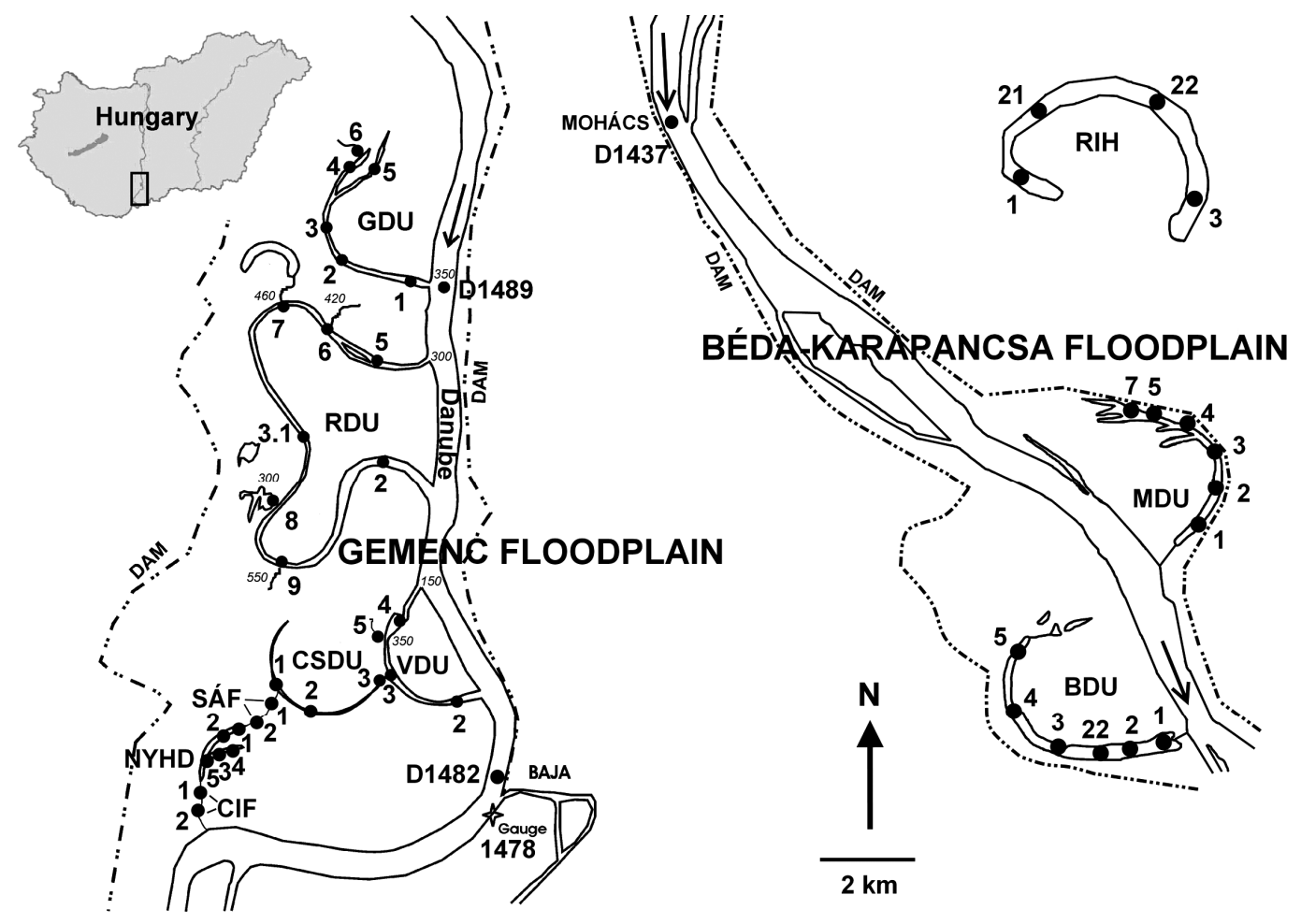

Figure 1. Sampling sites on the Gemenc-Béda-Karapancsa Floodplains (Gemenc floodplain: Grébeci-Holt-Danube (GDU), Rezéti-Holt-Danube (RDU), Vén-Danube (VDU), Cserta-Danube (CSDU), Sárkány-fok (SÁF), Nyéki-Holt-Danube (NYHD),

Címer-fok (CIF), Béda-Karapancsa floodplain: Riha oxbow (RIH), Mocskos-Danube (MDU), Külső-Béda (BDU)

vious studies (Bothár 1980: 28 taxa; Csányi et al. 1998: 15; Körmendi \& Lanszki 2002: 47; Körmendi 2007: 16) with the exception of the investtigation of Forró \& Meisch (1998) (111 taxa), but in our studies the area of sampling was more extensive and the duration of the survey was longer than any other studies. All of the species reported by Csányi et al. (1998) and Körmendi (2007) were also recorded in our studies. 27 species in the study of Bothár (1980), 43 in Körmendi and Lanszki (2002), as well as 73 taxa in the investigation of Forró and Meisch (1998) also occurred between 2002 and 2013.

There were significant differences in the species richness between water bodies with differing degrees of connectivity with the Danube (Appendix 1). Species richness was the highest in the plesiopotamon, which has no permanent and direct connection to the main arm. Among the newly detected species, Daphnia ambigua,
Pleuroxus denticulatus and Eurytemora velox are alien or non-native (allochtonous) species in Hungary. The abundance of thirty species was irrelevant; in these species less than 10 individuals were collected between 2002 and 2013. These were regarded as rare species in Gemenc-BédaKarapancsa Floodplains.

\section{Alien species}

The copepod genus Eurytemora occupies a wide range of habitat types throughout the Northern Hemisphere, with among the broadest salinity ranges of any known copepod. Eurytemora velox, as originally salt water species is widely distributed in the brackish waters from the Arctic Ocean and the Baltic Sea shore to Southeastern Europe, the Sea of Azov, and the Caspian Sea. This euryhaline species migrated from the estuaries of the North Sea upstream of many rivers (Tollinger 1911) and from the Black Sea 
upstream in the Danube River (Gaviria \& Forró 2000). In the Middle Danube Basin this species was collected for the first time in Hungary in 1991 (Forró \& Gulyás 1992), also in Slovakia (Vranovský 1994) and Austria (Gaviria \& Forró, $2000)$ in the very same year. In the last twenty years E. velox was presumably spread in the whole Hungarian section of the Danube and in many freshwater habitats of Hungary also. For example, in the Lake Ferto (the westernmost and largest steppe lake in Eurasia, situated on the Hungarian-Austrian border) this species showed up for the first time in 2009 then spread gradually and in 2012 a total of 492 specimens were collected (Kiss et al. 2014).

In the area of the Danube-Drava National Park the presence of E. velox was recorded in 2002 (Kiss \& Schöll 2009), the previous faunistic works (Körmendi 2007, Körmendi \& Lanszki 2002, Forró \& Meisch 1998) did not mention this species. In our investigation altogether 622 individuals of $E$. velox were collected between 2002 and 2013. Most of the individuals were in the plesiopotamal Mocskos-Danube (297 individuals) and the distribution of this calanoid differed significantly between the examined water bodies (Fig. 2. A). Larger part of the collected specimens occurred in the plesiopotamal wetlands which are situated close to the main arm and often connected with the Danube. Similarly to our observation in Lake Fertő (Kiss et al. 2014), the number of the collected individuals differed year by year and there was a significant increase from 2009 (Fig. 2. B).

In the sampled habitats this calanoid often coexisted with other calanoids, Eudiaptomus vulgaris and/or Eudiaptomus gracilis. The number of E. velox was significantly higher than the two Eudiaptomus species (Fig. 3.) similarly to the observation of Vad et al. (2012). Opposite to other observations, e.g. soda pan in western Hungary (Horváth \& Boros 2010) or two artificial lakes in the region of the North Hungarian Mountains (Vad et al. 2012), E. velox is still not a dominant member of Copepoda assemblages in Gemenc-Béda-Karapancsa Floodplain. In the area of Szigetköz (Northwestern Hungary, 1850-1793 rkm) the abundance of this species was also not significant at the monitoring sites of Szigetköz Monitoring Network between 1999 and 2013. During the fourteen years of monitoring only 155 specimens were collected from the three section of Szigetköz (main arm connected and reconnected floodplain).

Pleuroxus denticulatus is also an allochtonous species in the Middle Danube Basin. It was described from North America (Birge 1879) and its range is restricted to the northern hemisphere (Frey 1993). This North-American Cladocera occurs in Europe since the 1970s. This species is a new invader from Western to Central Europe and its occurrence in the Danube probably corresponds with the opening of the Rhine-MainDanube Canal (Hudec \& Illyová 1998). The first occurrence of $P$. denticulatus in the Hungarian section of the main channel was reported in 1992 at rkm1669 (Bothár 1994), since then it has been spread in the main arm (Gulyás 1995, Kiss \& Schöll 2009, Vadadi et al. 2009). Similar to $E$. velox, $P$. denticulatus was also not revealed by the previous studies from the Danube-Drava National Park (Körmendi 2007, Körmendi \& Lanszki 2002, Forró \& Meisch 1998, Csányi et al. 1998). In the study area, $P$. denticulatus was firstly collected in 2003 from the Cserta-Danube and Sárkány-fok, then it was spread the whole active floodplain, but in the protected side of the floodplain this species does not occur yet (Fig. 2. C).

According to our result, this species was spread in the whole river-floodplain system and it supposedly has permanent population in the floodplain, but its density was very low, only forty specimens were collected between 2003 and 2012. Similar trend can be observed in the area of Szigetköz, where only 67 individuals were collected between 1999 and 2013 (A. Kiss unpublished result). This alien cladoceran was mostly found in the littoral zone, between submerged or emergent macrophytes. It was usually found together with typical littoral cladocerans, especially Pleuroxus aduncus, P. truncatus, similar to the observations of Hudec and Illyová (1998) and Vad et al. (2012). 

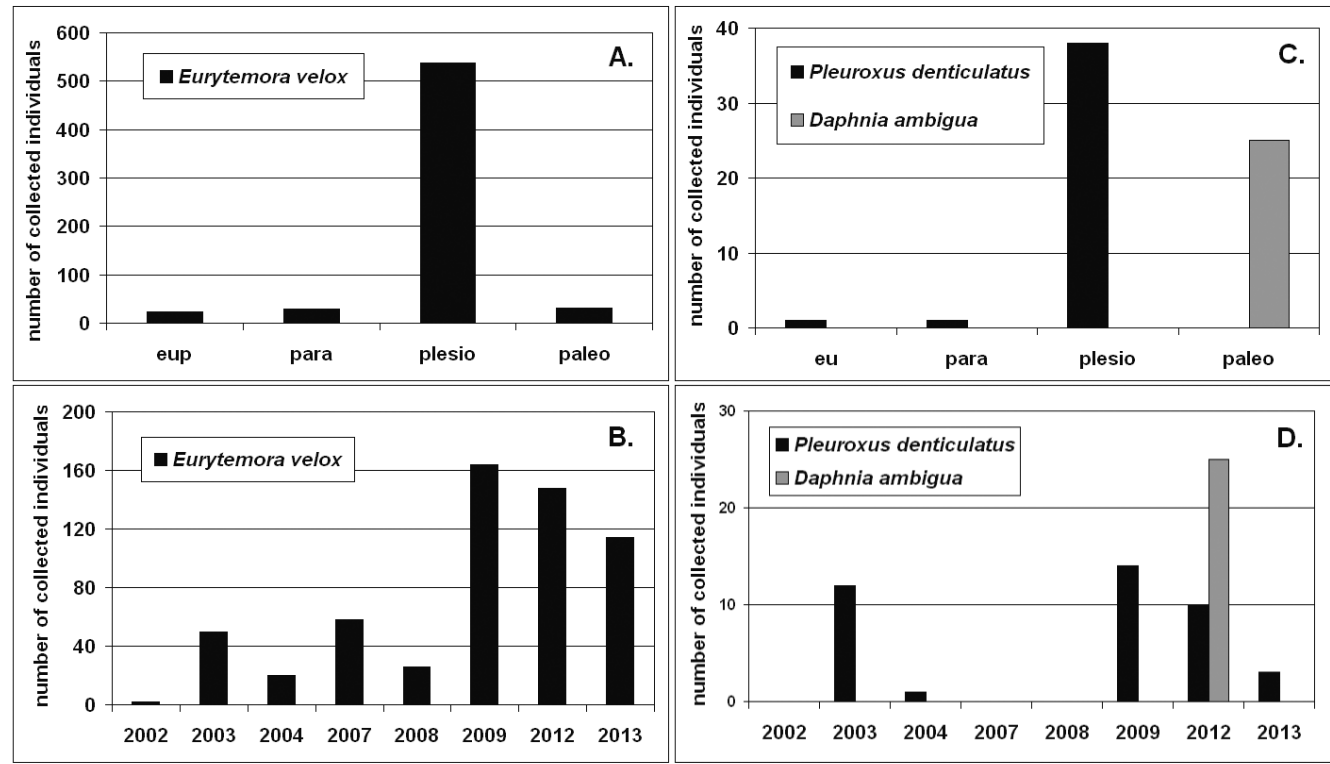

Figure 2. The distribution of the three alien species in the study area between 2002 and 2013 (A and $\mathrm{B}=$ Eurytemora velox, $\mathrm{C}$ and $\mathrm{D}=$ Daphnia ambigua and Pleuroxus denticulatus).

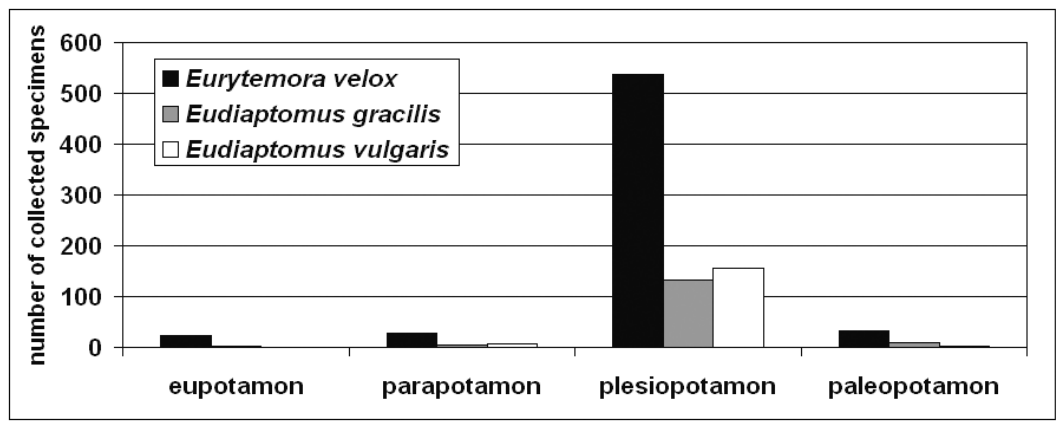

Figure 3. Distribution of the three Calanoida species in the study area between 2002 and 2013.

Daphnia ambigua, one of the most broadly distributed members of its genus, occurs in Europe as well as in North and South America (Herbert et al. 2003). This species is native to the temperate regions of North America and it was introduced to Europe where it is now broadly distributed (Maier 1996). Similarly to Pleuroxus denticulatus, it has been spreading from Western to Central Europe in the last few decades (Vranovský \& Terek 1996). In Hungary D. ambigua is a rare species, their presence was confirmed especially from the Danube (Gulyás \& Forró 1999, Kiss \& Schöll 2009), but Vad et al. (2012) found this species in an artificial lake in the region of the North Hungarian Mountains as well. In our studies D. ambigua was found only at two sampling sites of the paleopotamal Riha Oxbow, in May 2012. Only 25 individuals were collected together with Daphnia cucullata, D. longispina, Bosmina longirostris, Ceriodaphnia pulchella, Chydorus sphaericus, Eurytemora velox, and seven other species. In the area of Szigetköz (northwest Hungary) between 1999 and 2013, only one individual of $D$. ambigua was found in 2006, in the Schisler-dead arm (A. Kiss unpublished result).

It is obvious that Eurytemora velox and Pleuroxus denticulatus have a permanent population in Gemenc-Béda-Karapancsa Floodplains, 
but according to our results D. ambigua is still not permanent member of the fauna and its local and occasional presence could be correlated with birdmediated dispersal (Riha Oxbow is an important area used by migratory birds).

Species of zooplankton, especially cladocerans can easily spread with passive transport (via wind, water or birds), mainly due to their ability to create resting eggs (Havel et al. 1995). The role of human-mediated vectors is also noteworthy especially for species dispersal across geographical barriers and into large aquatic ecosystems. Diapausing stages facilitate species survival during movement across geographical barriers under extreme conditions, such as in ballast tanks of ships (MacIsaac et al. 2001).

\section{Rare species}

The abundance of thirty species (13 Cladocera, 10 Copepoda, 7 Ostracoda) is insignificant, less than ten individuals were collected between 2002 and 2013. In case of nine species only one individual was found in the whole period of sampling. Twenty-two species were mentioned by earlier works (Bothár 1980, Forró \& Meisch 1998, Körmendi \& Lanszki 2002, Körmendi 2007), accordingly these species are supposedly permanent members of the local fauna.

Most of the rare species were distributed in the connected floodplain, in the plesiopotamon and especially in the Nyéki-Holt-Danube (Fig. 4. AC). Among the sampling years, the number of rare species was the highest in 2003 and 2009. This result could be subsequent upon our sampling program and the hydrological events. In 2003 all of the potamon-types were investigated at the same time and extensive macrovegetation developed in many places in the floodplain because the water level was low in the main arm. In 2009, a detailed study was launched in the Nyéki-HoltDanube, which is the most diverse area in Gemenc-Béda-Karapancsa-Floodplains.

Among the rare species, Holopedium gibberum, Ceriodaphnia dubia, Cyclops insignis, Cypris pubera, Paracyclops affinis, Bradleystrandesia reticulata, Notodromas monacha and Paracandona euplectella are new species for the DanubeDrava National Park.

Holopedium gibberum is one of the most infrequent microcrustacean species in Hungary being reported only from the Danube (Gulyás \& Forró 1998). In our study, three individuals of Holopedium were collected in September 2007 from the Rezéti-Holt-Danube (Kiss \& Schöll 2009). In the beginning of September 2007 there was an extreme water level (797 cm, Baja gauge) in the flooding period and our sampling was in the receding period when the mixing floodplain waters start to flow back toward the main arm. This holarctic species prefers mainly cool, oligotrophic, soft-water lakes with low $\mathrm{pH}$ (Balcer et al. 1984) and it is noteworthy that the resting eggs of Holopedium are poorly adapted for transfers among habitats (Cox \& Hebert 2001). Supposedly we found a small temporary population of Holopedium, which was transported by the flood.

Similarly to Holopedium, the two individuals of Cyclops insignis were detected in September 2007 as well in the receding period of the flood. Both species prefer mainly small standing water habitats and lower water temperature. The carnivorous cladoceran, Polyphemus pediculus was also reported from many localities of Hungary (Gulyás \& Forró 1999), but only eight specimens was collected from Nyéki-Holt-Danube. Among the former works, it was only reported by Forró and Meisch (1998) from two localities of Drava region.

Out of the seven rare ostracods three (Bradleystrandesia reticulata, Candona weltneri, Paracandona euplectella) were collected in the NyékiHolt-Danube in 2003, when the water level of the oxbow was extremely low. These species prefer small water bodies with swampy or boggy bottom. The neustonic ostracod, Notodromas monacha is widely distributed across the Holarctic region and common everywhere in suitable habitats (Meisch 2000). In Hungary it is recorded from many localities and sometimes was multitudinous in the plankton (e.g. Kiss 2007). Curiously, the only collected specimen of Notodromas occurred in the main arm. 

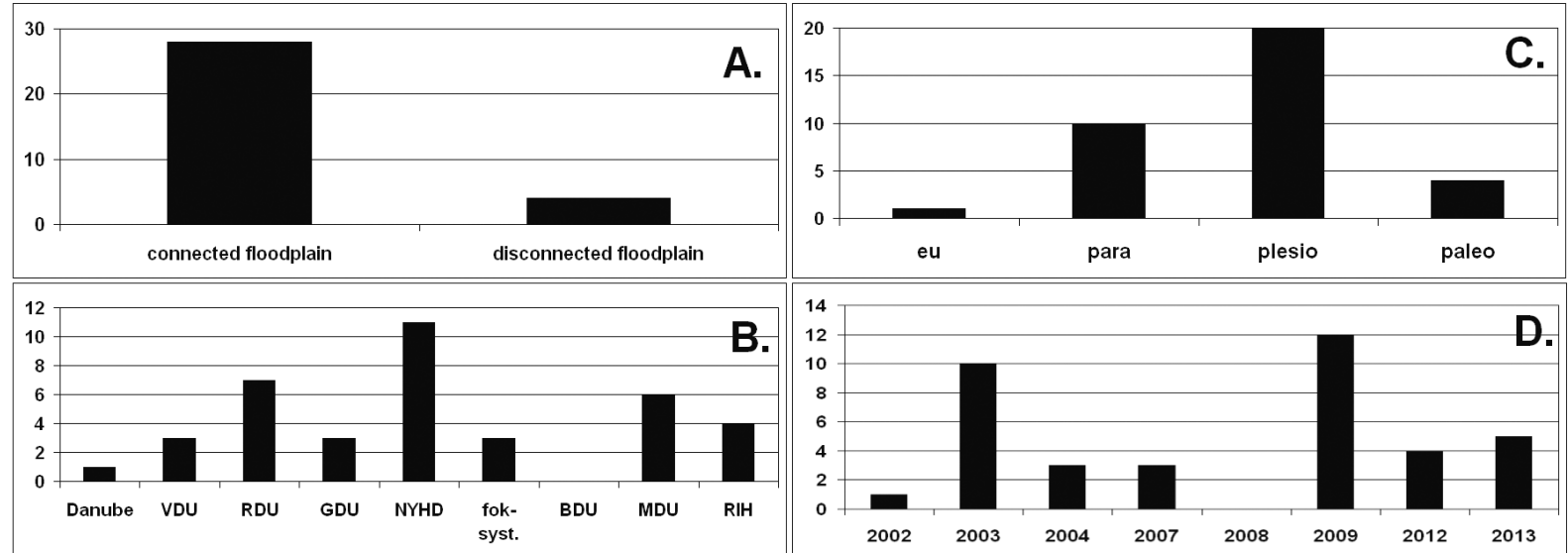

Figure 4. Species richness of the rare species in the study area. A = the number of taxa in the connected (eu-, para- and plesiopotamon) and in the disconnected (paleopotamon) floodplain, $\mathrm{B}=$ the number of taxa in the sampling sites, $\mathrm{C}=$ the number of taxa the different functional units, $\mathrm{D}=$ The occurrence of rare species in the different sampling years.

In our studies, the scarce occurrence of some taxa, e.g. benthic Paracyclops spp., Ectocyclops phaleratus, Harpacticoida or bottom-dwelling ostracods (Candonidae, Limnocythere) is evident because we did not collect from the benthos.

\section{Microcrustacean species richness in water bodies with differing degrees of con- nectivity with the main arm}

The species richness, the average, and maximum number of taxa were different in the studied water bodies and were the highest in the plesiopotamon (Fig. 5).

36 taxa $(\mathrm{N}=54)$ were collected from the eupotamon, the most frequent species were Bosmina longirostris, Chydorus sphaericus and Acanthocyclops robostus which are typical for the Hungarian section of Danube. The average number of taxa was 3.85 and the differences between the three sampling sites of the main arm were irrelevant.

In the parapotamon the species richness (57 taxa, $N=143$ ) and the number of rare taxa (10) increased and 9 taxa occurred in this functional unit alone. Among these species, Holopedium gibberum and Diaphanosoma mongolianum were found in the conjuctive water bodies in the receding period of the flood. These water bodies are small channels, branching out from side arms, hydrologically interconnecting them to the floodplain (Schöll et al. 2012). Compare to the main arm, there was no difference in the average number of taxa, 9 but the maximum number of taxa per sample (10) was higher than the eupotamon. The most significant species were the characteristic species of the main arm and Thermocyclops spp., but the tychoplanktonic and phytophilous taxa were also occurred.

The species richness (83 taxa: 45 Cladocera, 26 Copepoda, 12 Ostracoda) and the number of rare taxa (20), the average (7.23) as well as the maximum (22) number of taxa were the highest in the plesiopotamon. 28 taxa reported from the plesiopotamon alone and the number of tychoplanktonic and phytophilous taxa was significant. There were significant differences in the species richness between the studied plesiopotamal side arms. In the Gemenc-Béda-Karapancsa Floodplains, Nyéki-Holt-Danube was proved to significantly important area of microcrustacean diversity. Despite of the relatively small number of samples $(\mathrm{N}=50)$, the species richness (60 taxa) and the number of rare taxa (11) were the highest in the area. The species richness was also notably in the fok-system (41 taxa, $\mathrm{N}=13$ ), but contrary to this, only 22 taxa were detected in the Külső-Béda (22). 


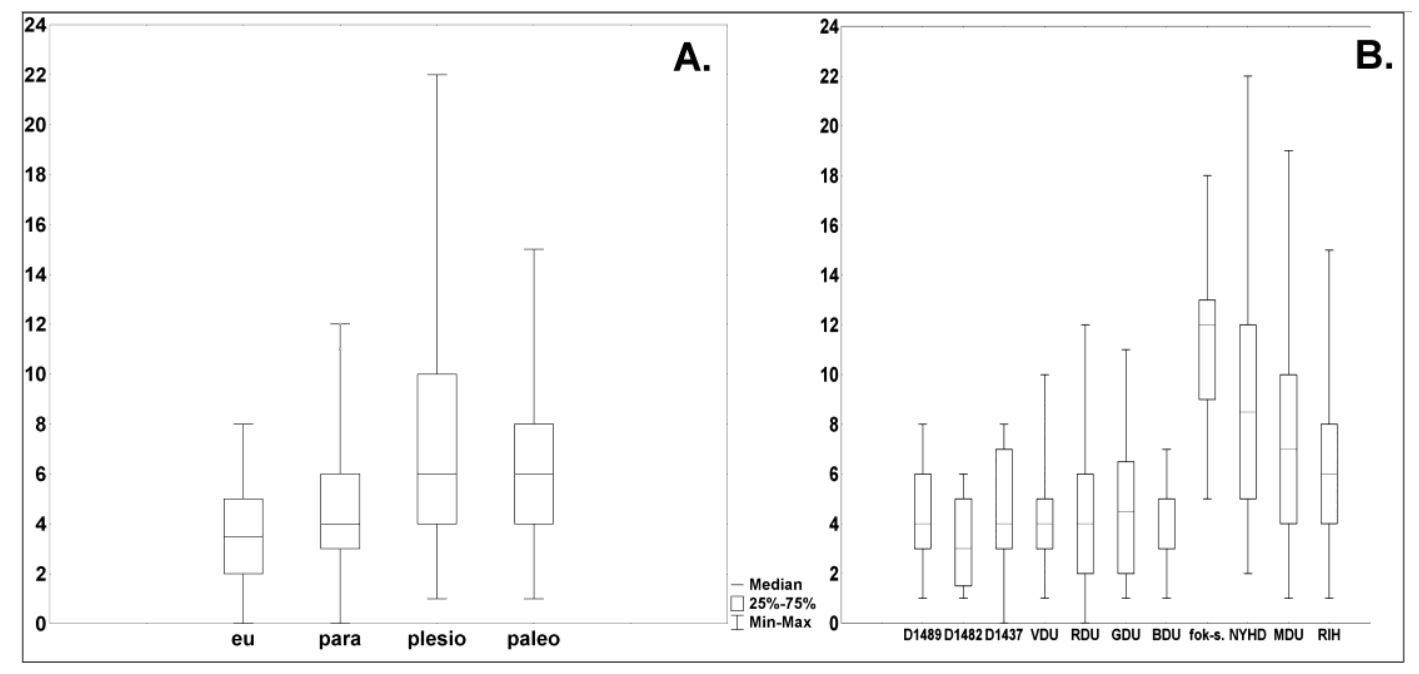

Figure 5. The species richness of microcrustaceans in the different potamon-types (A) and in the different sampling sites (B) ( see text for further explanation.)

In the paleopotamon $(\mathrm{N}=72) 43$ taxa were collected and average (6.23) and maximum number of species (15) as well as the number of rare taxa (4) decreased compare to the significant part of the plesiopotamal side arms. The high proportion of tychoplanktonic and phytophilous taxa in the assemblages is obvious. Many works (e.g. Tockner et al. 1998) published positive correlation between the species richness and the degree of connectivity between the main channel and the backwaters, but according to our observation the species diversity of microcrustaceans was the highest in the plesiopotamon and not in the disconnected floodplain.

\section{CONCLUSION}

Between 2002 and 2013101 taxa were recorded in the area of Gemenc-Béda-Karapancsa Floodplains and 18 species proved to be new for the region. The species richness and composition of the fauna were different in the examined floodplain water bodies and the number of microcrustacean species was most significant in the plesiopotamon. The fauna of the plesiopotamal Nyéki-Holt-Duna is noticeably diverse and this oxbow is a "diversity hotspot" in the floodplain. This study proved the presence of Dahnia ambigua, Pleuroxus denticulatus and Eurytemora velox and confirmed the expansion of these non-native species in the floodplain. $E$. velox and $P$. denticulatus have persistent populations in the area, but their contribution to floodplain biodiversity is still not significant. Daphnia ambigua has only local and temporal populations and its presence is confined to the disconnected side of the floodplain.

Acknowledgements - The study was supported by the NKFP-3B/0014/2002 and the Deutsche Bundesstiftung Umwelt (DBU, AZ 24050) projects.

\section{REFERENCES}

ÁGOSTON-SzaBÓ E., Schöll K. \& DinKa M. (2013): Limnological characteristics of a Danube oxbowlake (Danube-Drava National Park, Hungary). River Systems, 20(3-4): 277-287. doi: $10.1127 / 1868-5749 / 2013 / 0055$

ÁGOSTON-SzaBÓ E., SCHÖll K., KisS A., BerCZIK Á. \& DINKA M. (2014): Decomposition of willow leaf litter in an Oxbow Lake of the Danube River at Gemenc, Hungary. Acta Zoologica Bulgarica Suppl., 7: 197-202.

AMOros C. \& RouX A.L. (1988): Interaction between water bodies within the floodplains of large rivers: function and development of connectivity. Münstersche Geographische Arbeiten, 29: 125-130.

Amoros C., Roux A. L., Reygrobellet J. L., BRAVARD J. P. \& PAUTOU G. (1987): A method for applied ecological studies of fluvial hydrosystems. Regulated Rivers: Research \& Management, 1: 1736. doi: $10.1002 / \mathrm{rrr} .3450010104$ 
BALCER B.D., KORDA N.L. \& DODSON S.I. (1984): Zooplankton of the Great Lakes. The University of Wisconsin Press, Ltd. London, England. p. 56-58.

BIRGE E. A. (1879): Notes on Cladocera. Transactions of the Wisconsin Academy of Sciences, 4: 77-109.

BothÁR A. (1980): Vergleichende Untersuchung der Crustacea-Gemeinschaften im Nebenarm ,Alte Donau" und im Hauptstrom (stromkm 1481). Annales Universitatis Scientiarum Budapestinensis de Rolando Eötvös Nominatae. Sectio biologica, 22/23: 159-174.

BothÁR A. (1994): Qualitative und quantitative Planktonuntersuchungen in der Donau bei Göd/ Ungarn (1669 Stromkm) II. Zooplankton. 30. Arbeitstagung der IAD, Zuoz/Schweiz, Wissenschaft-liche Kurzreferate: 41-44.

DUSSART B. (1967): Les Copépodes des eaux continentáles. I. Calanoides et Harpacticoides. N. Borbée \& Cie, Paris, 500 pp.

DUSSART B. (1969): Les Copépodes des eaux continentáles. II. Cyclopoides et Biologie. N. Borbée \& Cie, Paris, 229 pp.

Cox A.J. \& HeBerT P. D. N. (2001): Colonization, extinction and phylogeographic patterning in a freshwater crustacean. Molecular Ecology, 10: 371-386. doi: 10.1046/j.1365-294x.2001.01188.x

CsÁnyi B., Sziebert J., NÉmeth J., Gulyás P., JuHÁSZ P., VIDA A., FELFÖLdY L. \& KALOCSA B. (1998): Base-line survey in the Gemenc Protected Landscape Area: hydrological, morphological, water quality and ecological data of the Vén-Duna, River Danube and Nyéki-Holt-Duna in 1997-1998, prior to restoration. RIZA, Institute for Inland Water Management and Waste Water Treatment of the Netherlands, Ministry of Transport, Public Works and Water Management. 58 pp.

FORRÓ L \& GULYÁS P. (1992): Eurytemora velox (Lilljeborg, 1853) (Copepoda, Calanoida) in the Szigetköz region of the Danube. Miscellanea Zoologica Hungarica, 7: 53-58.

ForRó L. \& MeISCH C. (1998): A Duna-Dráva Nemzeti Park Dráva menti vizeinek rákfaunája (Crustacea). Dunántúli Dolgozatok Természettudományi Sorozat, 9: 111-122.

FREY D. G. (1993): Species of Pleuroxus (Anomopoda, Chydoridae) from the subantarctic islands and southernmost South America: a partial unravelling of the Pleuroxus aduncus problem. Hydrobiologia, 262: 145-188. doi: 10.1007/BF00010882
GAVIRIA S. \& FORRÓ L. (2000): Morphological characterization of new populations of the copepod Eurytemora velox (Lilljeborg, 1853) (Calanoida, Temoridae) found in Austria and Hungary. Hydrobiologia, 438: 205-216. doi: 10.1023/A:1004173704289

GulyÁs P. (1995): Rotatoria and Crustacea plankton of the River Danube between Bratislava and Budapest. Miscellanea Zoologica Hungarica, 10: 7-19.

GULYÁS P. \& FORRÓ L. (1999): Az ágascsápú rákok (Cladocera) kishatározója 2. (bővített) kiadás. Vizi természet- és környezetvédelem, 9: 1-237.

GULYÁS P. \& FORRÓ L. (2001): Az evezőlábú rákok (Calanoida és Cyclopoida) alrendjeinek kashatározója 2. Bővített kiadás. Vizi természet- és környezetvédelem, 14: 1-200.

Guti G. (2001): Water bodies in the Gemenc floodplain of the Danube, Hungary. (A theoretical basis for their typology). Opuscula Zoologica Budapest, 23: 49-60.

Havel J. E., Mabee W. R. \& Jones J. R. (1995) Invasion of the exotic cladoceran Daphnia lumholtzi into North American reservoirs. Canadian Journal of Fisheries and Aquatic Sciences, 52: 151-160. doi: $\underline{10.1139 / \mathrm{f} 95-015}$

Hebert P. D. N., WitT J. D. S. \& AdAmowicz S. J. (2003): Phylogeographical patterning in Daphnia ambigua: Regional divergence and intercontinental cohesion. Limnology and Oceanography, 48(1): 261-268. doi: 10.4319/1o.2003.48.1.0261

Horváth Zs. \& Boros E. (2010) A magyar asztatikus szikes tavak nyár eleji kisrák-együtteseinek (Copepoda, Cladocera) faunisztikai és mennyiségi vizsgálata [Faunistical and quantitative investtigation on the early summer microcrustacean (Copepoda, Cladocera) assemblages of the Hungarian astatic soda ponds.]. Acta biologica debrecina: Supplementum oecologica hungarica, 22: 153-171. [in Hungarian with English abstract]

HudeC I. \& IllyovÁ M. (1998): Pleuroxus denticulatus (Crustacea: Anomopoda: Chydoridae): a new invader in the Danube Basin. Hydrobiologia, 368: 65-73. doi: 10.1023/A:1003261007489

KISS A. (2007): Factors affecting spatial and temporal distribution of Ostracoda assemblages in different macrophyte habitats of a shallow lake (Lake Fehér, Hungary). Hydrobiologia, 585: 89-98. doi: $\underline{10.1007 / \mathrm{s} 10750-007-0631-8}$ 
KISS A. \& SCHÖLL K. (2009): Checklist of the Crustacea (Cladocera, Ostracoda, Copepoda) fauna in the active floodplain area of the Danube (18431806, 1669 and 1437-1489 rkm). Opuscula Zoologica Budapest, 40: 27-39.

Kiss A., Ágoston-Szabó E. \& Dinka M. (2014): Microcrustacean community structure in the different water bodies of the Lake Fertö/Neusiedler See (Fertö-Hanság National Park, Hungary): new invaders, recurring and missing taxa. Opuscula Zoologica Budapest, 45: 3-16.

KIss A., Ágoston-Szabó E., Dinka M. \& BercziK Á. (2014): Microcrustacean (Cladocera, Copepoda, Ostracoda) diversity in three side arms in the Gemenc Floodplain (Danube River, Hungary) in different hydrological situations. Acta Zoologica Bulgarica Suppl., 7: 135-141.

KÖRMENDI S. (2007): Zooplankton vizsgálatok gemenci vizes élőhelyeken. Natura Somogyiensis, 10: 121-126. [in Hungarian with English abstract]

KÖRMENDI S. \& LANSZKI J. (2002): A Duna-Dráva Nemzeti Park különböző vizes élőhelyeinek zooplankton vizsgálata II. A Crustacea (Cladocera, Copepoda) fauna kvalitatív vizsgálata. Somogyi Múzeumok Közleményei, 15: 113-121. [in Hungarian with English abstract]

JunK W. J., BAYLEY P. B. \& SPARKS R. E. (1989): The flood pulse concept in river-floodplain systems. Canadian Special Publication of Fisheries and Aquatic Sciences, 106: 110-127.

MAIER G. (1996): Daphnia invasion: Population dynamics of Daphnia assemblages in two eutrophic lakes with particular reference to the introduced alien Daphnia ambigua, Journal Plankton Research, 18: 2001-2015. doi: 10.1093/plankt/18.11.2001

MacisaAC H. J., GRIGOROVICH I. A. \& RicCIARDi A. (2001): Invasion essay Reassessment of species invasions concepts: the Great Lakes basin as a model. Biological Invasions, 3: 405-416. doi: 10.1023/A:1015854606465

MEISCH C. (2000): Freshwater Ostracoda of Western and Central Europe. In. SCHWOERBEL, P. ZWICK (Eds.) Suesswasserfauna von Mitteleuropa 8/3. Spektrum Akademischer Verlag, Heidelberg, Berlin. 522 pp.

MEISCH C. \& FORRÓ L. (1997): Checklist of Recent Ostracoda (Crustacea) from Hungary. Miscellanea Zoologica Hungarica, 11: 33-48.
SCHÖLL K. \& KISS A. (2008): Spatial and temporal distribution patterns of zooplankton assemblages (Rotifera, Cladocera, Copepoda) in the water bodies of the Gemenc Floodplain (Duna-Dráva National Park, Hungary). Opuscula Zoologica Budapest, 39: 65-76.

SCHÖLl K., KisS A., DiNKA M. \& BERCZIK Á. (2012): Flood-pulse effects on zooplankton assemblages in a river-floodplain System (Gemenc Floodplain of the Danube, Hungary). International Review of Hydrobiology, 97: 41-57. doi: 10.1002/iroh.201111427

TOCKNER K., SchIEMER F. \& WARD W. (1998): Conservation by restoration: the management concept for a river-floodplain system ont he Danube River in Austria. Aquatic Conservation, 8: 71-86. doi: 10.1002/(SICI)1099-0755(199801/02)8:1< 71::AIDAQC265>3.0.CO;2-D

TOLLINGER M. A. (1911): Die geographische Verbreitung der Diaptomiden und anderer Süss- und Brackwasser-Gattungen aus der Familie der Centropagiden. Zoologische Jahrbücher, Abteilung für Systematik, Ökologie und Geographie der Tiere, 30: $1-302$

VAD Cs. F., HORVÁTH Zs., KISS K. T. \& ÁCS É. (2012): Microcrustacean (Cladocera, Copepoda) communities in artificial lakes in the region of the North Hungarian Mountains, with special reference to the adventive species. Acta Zoologica Academiae Scientiarum Hungaricae, 58: 47-61.

VADADI-FÜLÖP CS., HUFNAGEL L., JABLONSZKY GY. \& ZsUGA K. (2009): Crustacean plankton abundance in the Danube River and in its side arms in Hungary. Biologia, 64: 1184-1195. doi: $10.2478 / \mathrm{s} 11756-009-0202-8$

VRANOVSKÝ M. (1994): Eurytemora velox (Lilljeborg, 1853) (Crustacea, Copepoda), a new immigrant in the middle Danube. Biologia (Bratislava), 49: 167172.

VRANOVSKÝ M. \& JOZEF T. (1996): First records of Daphnia ambigua from the rivers Danube and Hron. Biologia (Bratislava), 51(2): 142.

WARD J. V \& STANFORD J. A. (1995): Ecological connectivity in alluvial river ecosystems and its disruption by flow regulation. Regulated Rivers, 11 : 105-119. doi: 10.1002/rrr.3450110109

ZINKE G. (1996): Das Projekt europäische SchwesterNationalparke an der Donau. Limnologische Berichte Donau, 31(Ergänzungsband 1): 577-584. 
Kiss et al.: Microcrustacean diversity in the Gemenc-Béda-Karapancsa Floodplains: rare and alien species

Appendix 1. List of Cladocera, Copepoda and Cladocera taxa collected in Gemenc-Béda-Karapancsa Floodplains between 2002 and 2013

\begin{tabular}{|c|c|c|c|c|c|c|c|c|c|}
\hline & \multirow{2}{*}{\begin{tabular}{c|} 
eup. \\
Danube
\end{tabular}} & \multicolumn{2}{|c|}{ parapotamon } & \multicolumn{5}{|c|}{ plesiopotamon } & \multirow{2}{*}{$\begin{array}{c}\text { paleop. } \\
\text { RIH }\end{array}$} \\
\hline & & RDU & VDU & GDU & NYHD & MDU & BDU & fok-syst. & \\
\hline Number of samples & 54 & 78 & 65 & 60 & 50 & 95 & 47 & 13 & 72 \\
\hline \multicolumn{10}{|l|}{ CLADOCERA } \\
\hline Acroperus harpae (Baird, 1834) & $\mathrm{X}$ & & & & $\mathrm{X}$ & $\mathrm{X}$ & & $\mathrm{X}$ & $X$ \\
\hline Alona affinis (Leydig, 1860) & & $\mathrm{X}$ & & & & & & & $\mathrm{X}$ \\
\hline Alona costata Sars, 1862 & $\mathrm{X}$ & $\mathrm{X}$ & $\mathrm{X}$ & $\mathrm{X}$ & $\mathrm{X}$ & $\mathrm{X}$ & & $\mathrm{X}$ & $\mathrm{X}$ \\
\hline Alona guttata Sars, 1862 & $\mathrm{X}$ & $\mathrm{X}$ & & $\mathrm{X}$ & & $\mathrm{X}$ & $\mathrm{X}$ & & \\
\hline Alona intermedia Sars, 1862 & & & & & $\mathrm{X}$ & $\mathrm{X}$ & & & \\
\hline Alona quadrangularis (O. F. M., 1785) & $\mathrm{X}$ & $\mathrm{X}$ & $\mathrm{X}$ & & & $\mathrm{X}$ & & $\mathrm{X}$ & $\mathrm{X}$ \\
\hline Alona rectangula Sars, 1862 & $\mathrm{X}$ & & & & $\mathrm{X}$ & & $\mathrm{X}$ & & \\
\hline Alonella excisa (Fischer, 1854) & & & & & $\mathrm{X}$ & $\mathrm{X}$ & & $\mathrm{X}$ & $\mathrm{X}$ \\
\hline Alonella nana (Baird, 1850) & & $\mathrm{X}$ & $\mathrm{X}$ & & $\mathrm{X}$ & & & $\mathrm{X}$ & $\mathrm{X}$ \\
\hline Bosmina coregoni Baird, 1857 & $\mathrm{X}$ & $\mathrm{X}$ & $\mathrm{X}$ & $\mathrm{X}$ & & $\mathrm{X}$ & & & \\
\hline Bosmina longirostris (O. F. M.,1785) & $\mathrm{X}$ & $\mathrm{X}$ & $\mathrm{X}$ & $\mathrm{X}$ & $\mathrm{X}$ & $\mathrm{X}$ & $\mathrm{X}$ & $\mathrm{X}$ & $\mathrm{X}$ \\
\hline Bosmina longispina Leydig, 1860 & & & $\mathrm{X}$ & & & $\mathrm{X}$ & & & \\
\hline Camptocercus rectirostris Schoedler, 1862 & & & & & $\mathrm{X}$ & & & & $\mathrm{X}$ \\
\hline Ceriodaphnia dubia Richard, 1894 & & & & & & & & & $\mathrm{X}$ \\
\hline Ceriodaphnia laticaudata P. E. M., 1867 & $\mathrm{X}$ & & & & & & $\mathrm{X}$ & $\mathrm{X}$ & \\
\hline Ceriodaphnia megops Sars, 1862 & $\mathrm{X}$ & & & & $\mathrm{X}$ & $\mathrm{X}$ & & $\mathrm{X}$ & $\mathrm{X}$ \\
\hline Ceriodaphnia pulchella Sars, 1862 & $\mathrm{X}$ & $\mathrm{X}$ & & & $\mathrm{X}$ & $\mathrm{X}$ & & & $\mathrm{X}$ \\
\hline Ceriodaphnia quadrangula (O.F.M., 1785) & $\mathrm{X}$ & & $\mathrm{X}$ & $\mathrm{X}$ & $\mathrm{X}$ & $\mathrm{X}$ & & $\mathrm{X}$ & $\mathrm{X}$ \\
\hline Ceriodaphnia reticulata (Jurine, 1820) & & & & $\mathrm{X}$ & $\mathrm{X}$ & & $\mathrm{X}$ & $\mathrm{X}$ & $\mathrm{X}$ \\
\hline Chydorus gibbus Sars, 1890 & & & & & $\mathrm{X}$ & & & & \\
\hline Chydorus sphaericus (O. F. M., 1776) & $\mathrm{X}$ & $\mathrm{X}$ & $\mathrm{X}$ & $\mathrm{X}$ & $\mathrm{X}$ & $\mathrm{X}$ & $\mathrm{X}$ & $\mathrm{X}$ & $\mathrm{X}$ \\
\hline Daphnia ambigua Scourfield, 1946 & & & & & & & & & $\mathrm{X}$ \\
\hline Daphnia cucullata Sars, 1862 & $\mathrm{X}$ & $\mathrm{X}$ & $\mathrm{X}$ & $\mathrm{X}$ & $\mathrm{X}$ & $\mathrm{X}$ & $\mathrm{X}$ & & $\mathrm{X}$ \\
\hline Daphnia hyalina Leydig, 1860 & & & $\mathrm{X}$ & & & & & & \\
\hline Daphnia longispina O. F. M., 1785 & $\mathrm{X}$ & $\mathrm{X}$ & & $\mathrm{X}$ & & & $\mathrm{X}$ & $\mathrm{X}$ & $\mathrm{X}$ \\
\hline Daphnia obtusa Kurz, 1874 & & & & & & $\mathrm{X}$ & & & \\
\hline Daphnia pulex Leydig, 1860 & & & & & $\mathrm{X}$ & & & & \\
\hline Diaphanosoma brachyurum (Liévin, 1848) & $\mathrm{X}$ & $\mathrm{X}$ & $\mathrm{X}$ & $\mathrm{X}$ & & $\mathrm{X}$ & $\mathrm{X}$ & & $\mathrm{X}$ \\
\hline Diaphanosoma mongolianum Uéno, 1938 & & $\mathrm{X}$ & & & & & & & \\
\hline Disparalona rostrata (Koch, 1841) & $\mathrm{X}$ & $\mathrm{X}$ & $\mathrm{X}$ & $\mathrm{X}$ & & & $\mathrm{X}$ & $\mathrm{X}$ & $\mathrm{X}$ \\
\hline Dunhevedia crassa King, 1853 & & $\mathrm{X}$ & & & $\mathrm{X}$ & & & & \\
\hline Eurycercus lamellatus (O. F. M., 1785) & & & & & $\mathrm{X}$ & & & & \\
\hline Graptoleberis testudinaria (Fischer, 1848) & $\mathrm{X}$ & & & $\mathrm{X}$ & $\mathrm{X}$ & $\mathrm{X}$ & & & $\mathrm{X}$ \\
\hline Holopedium gibberum Zaddach, 1855 & & $\mathrm{X}$ & & & & & & & \\
\hline Iliocryptus agilis Kurz, 1878 & $\mathrm{X}$ & $\mathrm{X}$ & $\mathrm{X}$ & $\mathrm{X}$ & $\mathrm{X}$ & & $\mathrm{X}$ & & \\
\hline Iliocryptus sordidus (Liévin, 1848) & & & $\mathrm{X}$ & & & & & & \\
\hline
\end{tabular}


Kiss et al.: Microcrustacean diversity in the Gemenc-Béda-Karapancsa Floodplains: rare and alien species

\begin{tabular}{|c|c|c|c|c|c|c|c|c|c|}
\hline & Danube & RDU & VDU & GDU & NYHD & MDU & BDU & fok-syst. & RIH \\
\hline Leydigia leydigi (Schoedler, 1863) & & & $\mathrm{X}$ & & & & & & \\
\hline Macrothrix hirsuticornis Norm. et Br., 1867 & $\mathrm{X}$ & $\mathrm{X}$ & $\mathrm{X}$ & $\mathrm{X}$ & & & & & \\
\hline Macrothrix laticornis (Fischer, 1848) & & $\mathrm{X}$ & $\mathrm{X}$ & & & & & & $\mathrm{X}$ \\
\hline Moina brachiata (Jurine, 1820) & $\mathrm{X}$ & $\mathrm{X}$ & $\mathrm{X}$ & $\mathrm{X}$ & $\mathrm{X}$ & $\mathrm{X}$ & $\mathrm{X}$ & & $\mathrm{X}$ \\
\hline Moina macrocopa (Straus, 1820) & & & & & $\mathrm{X}$ & & & & \\
\hline Moina micrura Kurz, 1874 & & & & & & $\mathrm{X}$ & & & \\
\hline Monospilus dispar Sars, 1862 & & & $\mathrm{X}$ & & & & & & \\
\hline Oxyurella tenuicaudis (Sars, 1862) & & & & & $\mathrm{X}$ & & & & \\
\hline Pleuroxus aduncus (Jurine, 1820) & $\mathrm{X}$ & $\mathrm{X}$ & $\mathrm{X}$ & $\mathrm{X}$ & $\mathrm{X}$ & $\mathrm{X}$ & & $\mathrm{X}$ & $\mathrm{X}$ \\
\hline Pleuroxus denticulatus Birge, 1879 & $\mathrm{X}$ & & $\mathrm{X}$ & & $\mathrm{X}$ & $\mathrm{X}$ & $\mathrm{X}$ & $\mathrm{X}$ & \\
\hline Pleuroxus laevis Sars, 1862 & & & & & $\mathrm{X}$ & $\mathrm{X}$ & & & \\
\hline Pleuroxus truncatus (O. F. M., 1785) & & $\mathrm{X}$ & $\mathrm{X}$ & $\mathrm{X}$ & $\mathrm{X}$ & $\mathrm{X}$ & & $\mathrm{X}$ & $\mathrm{X}$ \\
\hline Pleuroxus uncinatus Baird, 1850 & & $\mathrm{X}$ & & & & & & & \\
\hline Polyphemus pediculus (Linné, 1761) & & & & & $\mathrm{X}$ & & & & \\
\hline Pseudochydorus globosus (Baird, 1843) & & & & & & $\mathrm{X}$ & & & \\
\hline Scapholeberis mucronata (O. F. M., 1785) & $\mathrm{X}$ & $\mathrm{X}$ & $\mathrm{X}$ & $\mathrm{X}$ & $\mathrm{X}$ & $\mathrm{X}$ & $\mathrm{X}$ & $\mathrm{X}$ & $\mathrm{X}$ \\
\hline Scapholeberis rammneri Dum. \& P. 1983 & & $\mathrm{X}$ & & & & $\mathrm{X}$ & & & $\mathrm{X}$ \\
\hline Sida crystallina (O. F. M., 1776) & $\mathrm{X}$ & $\mathrm{X}$ & $\mathrm{X}$ & & $\mathrm{X}$ & $\mathrm{X}$ & & & $\mathrm{X}$ \\
\hline Simocephalus serrulatus (Koch, 1841) & & & & & $\mathrm{X}$ & & & & \\
\hline Simocephalus vetulus (O. F. M., 1776) & $\mathrm{X}$ & $\mathrm{X}$ & $\mathrm{X}$ & $\mathrm{X}$ & $\mathrm{X}$ & $\mathrm{X}$ & & $\mathrm{X}$ & $\mathrm{X}$ \\
\hline Tretocephala ambigua (Lilljeborg, 1900) & & & & & & & & & $\mathrm{X}$ \\
\hline \multicolumn{10}{|l|}{ COPEPODA } \\
\hline Acanthocyclops robustus (Sars, 1863) & $\mathrm{X}$ & $\mathrm{X}$ & $\mathrm{X}$ & $\mathrm{X}$ & $\mathrm{X}$ & $\mathrm{X}$ & $\mathrm{X}$ & $\mathrm{X}$ & $\mathrm{X}$ \\
\hline Canthocamptus staphylinus (Jurine, 1820) & $\mathrm{X}$ & $\mathrm{X}$ & & $\mathrm{X}$ & & & & $\mathrm{X}$ & \\
\hline Cyclops insignis Claus, 1857 & & $\mathrm{X}$ & & $\mathrm{X}$ & $\mathrm{X}$ & & & & \\
\hline Cyclops scutifer Sars, 1863 & & & & & $\mathrm{X}$ & & & & \\
\hline Cyclops strenuus Fischer, 1851 & & $\mathrm{X}$ & $\mathrm{X}$ & $\mathrm{X}$ & $\mathrm{X}$ & $\mathrm{X}$ & & $\mathrm{X}$ & \\
\hline Cyclops vicinus Uljanin, 1875 & $\mathrm{X}$ & $\mathrm{X}$ & $\mathrm{X}$ & $\mathrm{X}$ & $\mathrm{X}$ & $\mathrm{X}$ & $\mathrm{X}$ & $\mathrm{X}$ & $\mathrm{X}$ \\
\hline Diacyclops bicuspidatus (Claus, 1857) & & & $\mathrm{X}$ & $\mathrm{X}$ & $\mathrm{X}$ & & & & \\
\hline Ectocyclops phaleratus (Koch, 1838) & & $\mathrm{X}$ & & & & & & $\mathrm{X}$ & \\
\hline \multicolumn{10}{|l|}{ Eucyclops macruroides (Lilljeborg, 1901) } \\
\hline Eucyclops macrurus (Sars, 1863) & & & $\mathrm{X}$ & $\mathrm{X}$ & & $\mathrm{X}$ & & & \\
\hline Eucyclops serrulatus (Fischer, 1851) & $\mathrm{X}$ & $\mathrm{X}$ & $\mathrm{X}$ & $\mathrm{X}$ & $\mathrm{X}$ & $\mathrm{X}$ & $\mathrm{X}$ & $\mathrm{X}$ & $\mathrm{X}$ \\
\hline Eucyclops speratus (Lilljeborg, 1901) & & & & & & $\mathrm{X}$ & & & \\
\hline Eudiaptomus gracilis (Sars, 1863) & $\mathrm{X}$ & $\mathrm{X}$ & $\mathrm{X}$ & $\mathrm{X}$ & $\mathrm{X}$ & $\mathrm{X}$ & $\mathrm{X}$ & & \\
\hline Eudiaptomus vulgaris (Schmeil, 1896) & & $\mathrm{X}$ & & & $\mathrm{X}$ & & & & $\mathrm{X}$ \\
\hline Eurytemora velox (Lilljeborg, 1853) & $\mathrm{X}$ & $\mathrm{X}$ & $\mathrm{X}$ & $\mathrm{X}$ & $\mathrm{X}$ & $\mathrm{X}$ & $\mathrm{X}$ & $\mathrm{X}$ & $\mathrm{X}$ \\
\hline Macrocyclops albidus (Jurine, 1820) & & & & & $\mathrm{X}$ & $\mathrm{X}$ & & $\mathrm{X}$ & $\mathrm{X}$ \\
\hline Macrocyclops distinctus (Richard, 1887) & & & & & & $\mathrm{X}$ & & & \\
\hline Macrocyclops fuscus (Jurine, 1820) & & & & & & $\mathrm{X}$ & & $\mathrm{X}$ & \\
\hline Megacyclops viridis (Jurine, 1820) & & & $\mathrm{X}$ & $\mathrm{X}$ & $\mathrm{X}$ & $\mathrm{X}$ & & $\mathrm{X}$ & $\mathrm{X}$ \\
\hline Mesocyclops leuckarti (Claus, 1857) & $\mathrm{X}$ & $\mathrm{X}$ & $\mathrm{X}$ & $\mathrm{X}$ & $\mathrm{X}$ & $\mathrm{X}$ & & $\mathrm{X}$ & $\mathrm{X}$ \\
\hline
\end{tabular}


Kiss et al.: Microcrustacean diversity in the Gemenc-Béda-Karapancsa Floodplains: rare and alien species

\begin{tabular}{|c|c|c|c|c|c|c|c|c|c|}
\hline & Danube & RDU & VDU & GDU & NYHD & MDU & BDU & fok-syst. & RIH \\
\hline Paracyclops affinis (Sars, 1863) & & & & & $\mathrm{X}$ & & & $\mathrm{X}$ & \\
\hline Paracyclops fimbriatus (Fischer, 1853) & $\mathrm{X}$ & $\mathrm{X}$ & & & & & & & \\
\hline Paracyclops poppei (Rehberg, 1880) & & & & & $\mathrm{X}$ & & & & \\
\hline Thermocyclops dybowski (Lande, 1890) & & & & $\mathrm{X}$ & & & $\mathrm{X}$ & & \\
\hline Thermocyclops crassus (Fischer, 1853) & $\mathrm{X}$ & $\mathrm{X}$ & $\mathrm{X}$ & $\mathrm{X}$ & $\mathrm{X}$ & $\mathrm{X}$ & & $\mathrm{X}$ & $\mathrm{X}$ \\
\hline Thermocyclops oithonoides (Sars, 1863) & $\mathrm{X}$ & $\mathrm{X}$ & $\mathrm{X}$ & $\mathrm{X}$ & $\mathrm{X}$ & & $\mathrm{X}$ & $\mathrm{X}$ & \\
\hline \multicolumn{10}{|l|}{ OSTRACODA } \\
\hline Bradleycypris obliqua $($ Brady, 1868$)$ & & & & & & & & $\mathrm{X}$ & \\
\hline Bradleystrandesia reticulata (Zaddach, 1844) & & & & & $\mathrm{X}$ & & & $\mathrm{X}$ & \\
\hline Candona weltneri Hartwig, 1899 & & & & & $\mathrm{X}$ & & & & \\
\hline Candona sp. (juv.) & & & & $\mathrm{X}$ & $\mathrm{X}$ & $\mathrm{X}$ & & $\mathrm{X}$ & \\
\hline Cyclocypris laevis (O. F. M., 1776) & & $\mathrm{X}$ & & & & & & & \\
\hline Cyclocypris ovum (Jurine, 1820) & & $\mathrm{X}$ & $\mathrm{X}$ & & $\mathrm{X}$ & $\mathrm{X}$ & & & $\mathrm{X}$ \\
\hline Cypria ophtalmica (Jurine, 1820) & & $\mathrm{X}$ & & & $\mathrm{X}$ & $\mathrm{X}$ & $\mathrm{X}$ & $\mathrm{X}$ & $\mathrm{X}$ \\
\hline Cypris pubera O. F. M., 1776 & & $\mathrm{X}$ & & $\mathrm{X}$ & & & & & \\
\hline Cypridopsis vidua (O. F. Müller, 1776) & & & $\mathrm{X}$ & $\mathrm{X}$ & $\mathrm{X}$ & $\mathrm{X}$ & & $\mathrm{X}$ & $\mathrm{X}$ \\
\hline Dolerocypris fasciata (O. F. Müller, 1776) & & & & & $\mathrm{X}$ & & & & \\
\hline Limnocythere inopinata (Baird, 1843) & & $\mathrm{X}$ & & & & & & & \\
\hline Notodromas monacha (O. F. Müller, 1776) & $\mathrm{X}$ & & & & & & & & \\
\hline Paracandona euplectella (Robertson, 1889) & & & & & $\mathrm{X}$ & & & & \\
\hline Physocypria kraepelini G. W. Müller, 1903 & & $\mathrm{X}$ & & $\mathrm{X}$ & $\mathrm{X}$ & & & $\mathrm{X}$ & \\
\hline Pseudocandona compressa $($ Koch, 1838) & & & & & & & & $\mathrm{X}$ & \\
\hline Pseudocandona sp. (juv.) & & & & & & & & & $\mathrm{X}$ \\
\hline Ostrcacoda sp. (juv.) & & & & & & & & & $\mathrm{X}$ \\
\hline Number of Taxa: & 36 & 47 & 39 & 38 & 60 & 46 & 22 & 41 & 43 \\
\hline
\end{tabular}

